\title{
The Distribution of Ascorbic Acid, Dehydroascorbic Acid, and Diketogulonic Acid in the Acerola Fruit at Different Stages of Development ${ }^{1}$
}

\author{
Alice del Campillo and Conrado F. Asenjo2
}

\section{INTRODUCTION}

Ascorbic acid (AA), dehydroascorbic acid (DHA), and 2, 3-diketogulonic acid (DKA) usually occur in this decreasing order in fresh plant tissue.

The reaction $\mathrm{AA} \rightleftarrows \mathrm{DHA}$ is freely reversible in plant as well as in other living tissues. Ascorbic acid oxidase $(1)^{3}$ directly, and at least four other enzyme systems $(2,3,4,5)$ indirectly, are known to catalyze this reaction in vivo. Hydrogen sulfide, among other reagents, may be used to reduce the oxidized form in the laboratory. However, the dehydro form, except in rather acid solution, undergoes in vitro, and probably also in vivo, a nonenzymatic hydrolysis at the lactone ring with the formation of diketogulonic acid. The reverse of this reaction does not occur in living tissue, as far as is known, although it can be accomplished in vitro. Considering the high ascorbic acid content of the acerola fruit (Malpighia punicifolia $L$.) (6), the following investigation was undertaken in order to determine the distribution of the three acids in this unusual fruit. No information was found in the literature regarding the distribution of $\mathrm{AA}, \mathrm{DHA}$, and DKA in the acerola fruit at different stages of development.

\section{OBJECTIVE}

It was the purpose of this investigation to determine the quantities of $\mathrm{AA}$, DHA, and DKA present in the acerola fruit from its very early flowering stage to the fully developed ripe fruit. Observations were made on fresh fruits as well as on fruits that had been frozen in a deep freeze for several days.

\section{MATERIAL AND METHODS}

In order to undertake this study, we arbitrarily divided the development of the acerola fruit into five stages: Stage 1, flower bud; stage 2, rudimentary

1 This research was made possible by a grant made to one of us (C.F.A.) by the Guggenheim Foundation. The technical assistance of Evangelina Recio is gratefully acknowledged.

2 Department of Biochemistry and Nutrition, School of Medicine, School of Tropical Medicine, San Juan 22, P. R.

3 Italic numbers in parentheses refer to Literature Cited, pp. 165-6. 
fruit; stage 3, green fruit, about 40 percent of final size; stage 4 , green fruit, about 70 percent of final size; stage 5 , red-ripe mature fruit ${ }^{4}$.

The method used for the differential determination of AA, DHA, and DKA was that of Roe, Mills, Oesterling, and Damron (7). It is based on the principle that 2,4-dinitrophenylhydrazine condenses with DHA and DKA but not with $\mathrm{AA}$. In order to differentiate the three acids three tubes containing the same aliquot of the unknown were used. The aliquot in tube 1 was reduced with hydrogen sulfide, that in tube 2 was left untreated, and the one in tube 3 was oxidized with bromine. After coupling with 2,4-dinitrophenylhydrazine had been accomplished, the condensation derivative obtained from the first tube was a measure of the DKA; that from the second tube of the DHA and DKA; and that from the third tube of the AA, DHA, and DKA. Therefore, by subtracting the first result from the second, and the second from the third, the quantity of DHA and AA, respectively, present in the sample, was calculated.

The detailed procedure was as follows: $1 \mathrm{gm}$. of the fruit ${ }^{5}$ was extracted in a chilled mortar with cold 5-percent thiourea-5-percent metaphosphoric acid mixture ${ }^{6}$ using small volumes to start, i.e., $3 \mathrm{ml}$. A good homogenate was obtained; the extraction was carried out for about 3 minutes. About $3 \mathrm{ml}$. more of the thiourea-metaphosphoric acid mixture was added, and the extraction was continued for another 3 minutes. This procedure was repeated again using $3 \mathrm{ml}$. of thiourea-metaphosphoric acid. The homogenate was then made up to $20 \mathrm{ml}$. by adding more of the thiourea-metaphosphoric acid mixture, and an additional $80 \mathrm{ml}$. of 5-percent metaphosphoric acid, so that the final concentration was 1-percent thiourea and 5-percent metaphosphoric acid. The green suspension was then filtered through fluted paper. The filtrate was fairly clear and was kept cold.

\section{DETERMINATION OF DIKETOGULONIC ACID}

Twenty-five milliliters of the clear filtrate was gassed for 10 minutes with hydrogen sulfide while keeping the filtrate in an ice-bath. The solution saturated with hydrogen sulfide was then gassed with carbon dioxide for 15 to 25 minutes. Two aliquots were taken for the assay.

\section{DETERMINATION OF DHA AND DKA}

The filtrate was used after the extraction and before gassing with hydrogen sulfide. Two aliquots were taken for the assay.

4 We are indebted to the Acerola Processing Corp. for permitting us to collect the fruits used in this investigation at their plantation at Sabana Seca, P. R.

${ }^{6}$ Stems were removed; after stage 2 the seeds were removed and the pulp alone was used.

- Roe and Oesterling (8) found that the addition of thiourea to the metaphosphoric acid solution used for extracting plant tissues prevented the oxidation of AA to DHA and kept at a minimum the spontaneous change of DHA to DKA. 


\section{DETERMINATION OF AA, DHA, AND DKA}

The remainder of the hydrogen sulfide-gassed solution was gassed with carbon dioxide and then aerated for about 5 minutes. A few drops of bromine were added until a yellow color persisted. The excess bromine was removed by aeration. A white precipitate of bromothiourea was obtained occasionally which was removed by filtration. This precipitate did not affect

TABLE 1.-Distribution of $D H A, D K A$, and $A A$ in fresh and frozen acerola fruits at different stages of development

\begin{tabular}{l|c|c|c|c|c|c|c|c}
\hline Stage of development & $\begin{array}{r}\text { Sam- } \\
\text { ples }\end{array}$ & DHA & DKA & AA & $\begin{array}{c}\text { Total as } \\
\text { AA }\end{array}$ & DHA & DKA & AA \\
\hline
\end{tabular}

Frozen fruits

\begin{tabular}{l|r|r|r|r|r|r|r|r}
\hline 1, Flower bud & 3 & 297.5 & 336.3 & 29.5 & 663.3 & 44.8 & 50.7 & 4.5 \\
2, Rudimentary fruit & 5 & 364.3 & 333.7 & $1,468.0$ & $2,166.4$ & 16.8 & 15.5 & 67.7 \\
$\begin{array}{c}\text { 3, Green fruit 40 per- } \\
\text { cent of mature size }\end{array}$ & 3 & 57.2 & 123.2 & $2,378.0$ & $2,558.7$ & 2.2 & 4.8 & 93.0 \\
$\begin{array}{c}\text { 4, Green fruit 70 per- } \\
\text { cent of mature size }\end{array}$ & 4 & 81.2 & 138.6 & $2,505.0$ & $2,724.8$ & 3.0 & 5.0 & 92.0 \\
$\begin{array}{l}\text { 5, Red-ripe mature } \\
\text { fruit }\end{array}$ & 5 & 87.5 & 123.4 & $1,412.0$ & $1,622.9$ & 5.4 & 7.6 & 87.0 \\
\hline
\end{tabular}

the final results. Two aliquots were taken for the assay. Each of the aliquots was made up to $4 \mathrm{ml}$. with the 1-percent thiourea and 5-percent metaphosphoric acid mixture. Two drops of 10-percent thiourea in 50-percent ethanol (optional in this case) were added to each tube. One milliliter of 2-percent dinitrophenylhydrazine in $9 \mathrm{~N}$ sulfuric acid was added to the experimental tube. The tubes were incubated overnight at room temperature and then the color was developed by adding 85-percent $\mathrm{H}_{2} \mathrm{SO}_{4}$.

A standard solution of ascorbic acid, $0.2 \mathrm{mg}$. per ml. in 5-percent metaphosphoric acid, was diluted 1:40 with 5-percent metaphosphoric acid and a 4-ml. aliquot was taken for the assay; $4 \mathrm{ml}$. $=20 \mu \mathrm{g}$. ascorbic acid. 


\section{RESULTS}

The results are given in table 1 . The values obtained for $\mathrm{AA}, \mathrm{DHA}$, and DKA at different stages of growth indicated that ascorbic acid is fairly stable, and that DHA and, especially DKA, are products of decomposition rather than of normal metabolism, as was suggested by Damron, et al. (9) in animal tissues. In general, there is more DHA than DKA in the fresh fruits, and more DKA than DHA in the frozen ones. In the formed fruit (stages 3,4 , and 5) the percentage of DHA and DKA ranged from 4 to 10 percent in fresh fruits, whereas in frozen ones it ranged from 7 to 13 percent. In the flower buds (stage 1) and rudimentary fruit (stage 2) freezing caused a marked conversion of the ascorbic acid into DHA and DKA, ranging from 32 to 95 percent.

\section{DISCUSSION}

These results indicate that the fresh fruit contains 1 to 4 percent of the total ascorbic acid present as the biologically inactive DKA. This value increases on freezing the fruit, as can be seen in table 1. In general, our results are in agreement with those obtained by Mills, et al. (10) for the determination of DHA, DKA, and AA in fresh and processed foods. They found that the majority of fresh foods assayed showed less than 5 percent of the total vitamin C-like compounds present as DKA. Processed foods contained more of the oxidized forms of ascorbic acid, and dehydrated foods showed the greatest amount of the inactive DKA.

The data collected have clearly shown that after stage 1, the fresh fruit starts to accumulate ascorbic acid at a very rapid rate; from $544.9 \mathrm{mg}$. per $100 \mathrm{gm}$. at stage 1 to $2,167.5 \mathrm{mg}$. per 100 at stage 2 , an increase of the order of 300 percent. Similar changes were observed in the frozen fruit. This sudden appearance of large quantities of ascorbic acid could possibly indicate that the enzymatic system responsible for ascorbic acid synthesis reaches its optimum efficiency at this early stage of fruit development. The ascorbic acid present at stage 1 is about 19 percent of the maximum attained at stage 4 , however at stage 2 it is already nearly 78 percent, while at stage 5 the content of ascorbic acid starts to decline, probably due to decomposition, and that left is only 63 percent of the maximum. The same sequence of events holds true of the frozen fruits.

\section{SUMMARY}

1. The values obtained for ascorbic acid (AA), dehydroascorbic acid (DHA), and diketogulonic acid (DKA) at different stages of growth of the fruit indicated that ascorbic acid is fairly stable in the acerola fruit and that the small content of DHA and DKA, especially of the second, are products of decomposition rather than of normal metabolism. 
2. In the fresh fruit at all stages of development the content of AA was never below 90 percent of the sum of the three components studied. DHA or DKA never attained individual values above 6 percent; however, the content of DHA was always slightly greater than that of DKA.

3 . In the frozen bud and rudimentary fruit there was a very significant increase in DHA and DKA and a corresponding reduction in AA. However, at higher stages of development AA was always in the neighborhood of 90 percent. There was more DKA than DHA in the frozen fruit.

4. During the formation of the rudimentary fruit (stages 1 to 2 ) there was a rapid increase in ascorbic acid, probably due to an optimum condition of the enzymatic system in the fruit responsible for ascorbic acid synthesis.

5. In the red-ripe fruit there was a significant lowering of ascorbic acid content.

\section{RESUMEN}

1. Los valores obtenidos para los ácidos ascórbicos (AA), dehidroascórbico $(\mathrm{ADH})$ y dicetogulónico $(\mathrm{ADC})$ durante las diferentes etapas del desarrollo de la fruta indicaron que el AA era bastante estable en la fruta de la acerola y que el pequeño contenido de $\mathrm{ADH}$ y $\mathrm{ADC}$, especialmente del segundo, son productos de descomposición más que de metabolismo.

2. En la fruta fresca, en todas las etapas de crecimiento estudiadas, el contenido de AA nunca fué menor del 90 por ciento de la suma de los tres compuestos estudiados. ADH o ADC nunca llegaron a tener valores individuales sobre 6 por ciento, sin embargo, el contenido de $\mathrm{ADH}$ fué siempre algo mayor que el de $\mathrm{ADC}$.

3. En los botones de flor o en las frutas rudimentarias congeladas se observó un aumento muy significativo en ADH y ADC y una disminución correspondiente en AA. Sin embargo, en etapas más avanzadas de crecimiento, AA siempre se mantuvo en la vecindad del 90 por ciento. En el caso del fruto congelado el ADC se encuentra en cantidad algo mayor que el $\mathrm{ADH}$.

4. Durante la formación del fruto rudimentario (etapa 1 a 2) se observó un rápido aumento en $\mathrm{AA}$, debido probablemente a condiciones óptimas en el sistema encimático responsable de la síntesis de ácido ascórbico en el fruto.

5. En el fruto maduro se observó una disminución significativa de ácido ascórbico.

\section{LITERATURE CITED}

1. Tauber, H., Kleiner, I. S., and Mishkind, D., Ascorbic acid (vitamin C) oxidase, J. Biol. Chem., 110 211-8, 1935.

2. Szent-Gyorgi, A., Observations on the function of peroxidase systems and the chemistry of the adrenal cortex, Biochem. J., 22 1387-1409, 1928. 
3. Huszak, Istvan (Stefan), The function of the peroxidase systems of plants, $Z$. Physiol. Chem., 247 239-47, 1937.

4. Johnson, S. W., and Zilva, S. S., The relation between the rate of enzymic oxidation and the stereochemical structure of ascorbic acid and its analogues, Biochem. $J ., 31$ 1366-74, 1937.

5. Keilin, D., and Hartree, E. F., Cytochrome oxidase, Proc. Roy. Soc. London, 125B 171-86, 1938.

6. Asenjo, C. F., and Freire de Guzmán, A. R., The high ascorbic acid content of the West Indian cherry, Sci. $103219,1946$.

7. Roe, J. H., Mills, M. B., Oesterling, M. J., and Damron, C. M., The determination of diketo-l-gulonic acid, dehydro-l-ascorbic acid, and l-ascorbic acid in the same tissue extract by the 2,4-dinitrophenylhydrazine method, J. Biol. Chem., 174 201-8, 1948.

8. Roe, J. H., and Oesterling, M. J., The determination of dehydroascorbic acid and ascorbic acid in plant tissue by the 2,4-dinitrophenylhydrazine method, J. Biol. Chem., 162 511-17, 1944.

9. Damron, C. M., Mills, M. M., and Roe, J. H., Metabolism of 1-ascorbic acid, dehydro-l-ascorbic acid, and diketo-l-gulonic acid in the guinea pig, J. Biol. Chem., 195 599-606, 1952.

10. Mills, M. M., Damron, C. M., and Roe, J. H., Ascorbic acid, dehydroascorbic acid, and diketogulonic acid in fresh and processed foods, Anal. Chem. 21 707-9, 1949. 